\title{
Ethics and bioprospecting in Antarctica
}

\author{
Ann-Isabelle Guyomard* \\ Centre de Droit Maritime et Océanique (CDMO), Faculté de Droit et des Sciences Politiques, Université de Nantes, \\ Chemin de la Censive du Tertre, BP 81307, 44313 Nantes Cedex 3, France
}

\begin{abstract}
Bioprospecting is a current activity in Antarctica, especially in the Southern Ocean, where numerous genetic resources have already been extracted and patented. At the global level, the Agreement on Trade-Related Aspects of Intellectual Property Rights, the Convention on Biological Diversity and the United Nations Convention on the Law of the Sea are the normal legal instruments for bioprospecting. These instruments are all based on territoriality and incorporate government restriction of access to resources. However, in Antarctica, the Antarctic Treaty System has been built over the past $50 \mathrm{yr}$ on fundamental ethical principles comprising peace, a freeze on territorial claims, freedom of scientific research, international cooperation, and environmental protection in the interest of mankind as a whole. How can bioprospecting be organized in Antarctica to match these ethical concerns without a sovereign governance structure that is predicated in the global instruments? At the global level, the current instruments seem inadequate because of the lack of acceptance of territorial claims existing in Antarctica; at the regional level, the existing system of Antarctic law still lacks concepts and criteria necessary to underpin the development of this activity with respect to the ethical principles and in a form likely to be transferred into national legislation. The solution for bioprospecting in Antarctica therefore needs to be the creation of an ad hoc Antarctic legal regime.
\end{abstract}

KEY WORDS: Ethics $\cdot$ Bioprospecting $\cdot$ Antarctica $\cdot$ Southern Ocean $\cdot$ Antarctic Treaty $\cdot$ PEPAT CCAMLR · CRAMRA Resale or republication not permitted without written consent of the publisher

\section{INTRODUCTION}

The end of the twentieth century has witnessed a new development in the scientific arena with the development of bioprospecting activities. Currently described as the 'systematic search for genes, natural compounds, designs, and whole organisms in wildlife with a potential for product development by biological observation and biophysical, biochemical, and genetic methods, without disruption to nature, $\underline{1}$ these activities exist in all parts of the world. More specifically in Antarctica, the exploitation of genetic resources currently concerns different types of ecosystems: ${ }^{2}$

These products include nutraceuticals from krill oil, antifreeze proteins, anticancer drugs, enzymes and com-

${ }^{1}$ The Encyclopedia of Biodiversity. See Levin (2000). pounds for cosmetic products. [...] Much of the commercial activity has focused on the marine environment, in particular krill. The rest is based on a variety of Antarctic source organisms which include microorganisms, invertebrates (such as sponges), vertebrates (such as fish), and plants (such as algae and Antarctic hairgrass). ${ }^{3}$

Several genetic resources extracted from organisms living in the Antarctic region are already used for medical or pharmaceutical goals. For instance, the hydro-

\footnotetext{
${ }^{2}$ Bioprospecting in Antarctica concerns terrestrial (38 percent; terrestrial and inner water ecosystems contribute respectively to 34 percent and 4 percent of this amount) and marine (56 percent) organisms. See the University of the United Nations database: www.bioprospector.org See also ATCM XXXI/WP011 in Appendix 1

${ }^{3}$ See the University of the United Nations database (www. bioprospector.org) and the document ATCM XXXI/WP011, op. cit.
} 
lase enzyme extracted from the krill Euphausia superba is used in the treatment and prevention of immune rejection reactions ${ }^{\mathbf{4}}{ }^{-}$astromelanin, derived from the Antarctic black yeast Nadsoniella nigra, helps in the treatment of pathological conditions, various pain syndromes, stress, immune problems, psychoemotional disorders, and so on. $\underline{5}$ Genetic resources can also serve various other fields such as chemistry, ${ }^{\mathbf{6}}$ agriculture ${ }^{\mathbf{7}}$ aquaculture ${ }^{\underline{\mathbf{8}}}$ environmental remediation, $\underline{\underline{9}}$ and commercial applications such as in the cosmetics,$\underline{10}$ food, beverage,,$\underline{11}$ and paper industries. ${ }^{12}$ As

${ }^{4}$ This use is described, among other things, as 'a method of preventing or ameliorating transplantation rejection reactions comprising treating the donor tissue with a rejection reaction preventing or ameliorating effective amount of a hydrolase that is effective reduce [sic] the amount of one or more cell surface adhesion molecules. One very particular embodiment uses a krill-derived multifunctional enzyme and a family of crustacean and fish derived enzymes having substantial structural or functional similarity to the multifunctional enzyme derived from Antarctic krill.' University of the United Nations database: www.bioprospector.org/bioprospector/antarctica/entry.action?page $=2 \&$ searchQuery.qu ery $=\&$ search Query.researchArea=5\&searchQuery.organisation $=-1 \&$ searchQuery. country=-1\&id=26

${ }^{5}$ University of the United Nations database: www.bioprospector.org/bioprospector/antarctica/entry.action?page $=2 \&$ searc hQuery.query $=\&$ searchQuery.researchArea $=9 \&$ searchQuery. organisation $=-1$ \&searchQuery. country $=-1 \& i d=48$

${ }^{6}$ See, for instance, the use of the yeast Candida antarctica in the 'process for stereoselection of $(2 \mathrm{R}, 3 \mathrm{~S})$-3-phenylgycidic ester using lipase.' University of the United Nations database: www.bioprospector.org/bioprospector/antarctica/entry. action?id=84

${ }^{7}$ See, for instance, the use of Antarctic hair grass Deschampsia antarctica in 'the modification of plant response to freezing and/or low temperature stress.' University of the United Nations database: www.bioprospector.org/bioprospector/ant arctica/entry.action?page $=2 \&$ searchQuery.query $=\&$ search Query.researchArea $=1 \&$ search Query.organisation $=-1 \&$ searc hQuery. country=-1\&id=135

${ }^{8}$ See, for instance, the antifreeze gene extracted from the fish Nototheniidae used 'to develop rapidly growing salmon, trout and other finfish.' University of the United Nations database: www.bioprospector.org/bioprospector/antarctica/ entry.action?id=74

${ }^{9}$ See, for instance, the bacterium Rhodococcus spp. used in the bioremediation of hydrocarbon-contaminated soils at Palmer station (Antarctica). University of the United Nations database: www.bioprospector.org/bioprospector/antarctica/ entry.action?id=61

${ }^{10}$ See, for instance, the algae Durvillea antarctica used in an extra firming day cream: (www.bioprospector.org/bioprospector/antarctica/entry.action?id=58)

11 See for instance the lichen Umbilicaria Antarctica whose protein is used as an antifreeze. University of the United Nations database: www.bioprospector.org/bioprospector/ antarctica/entry.action?id=19

${ }^{12}$ See, for instance, the yeast Candida Antarctica used 'in the process for hydrolysis of water-insoluble ester in the presence of a lipase.' University of the United Nations database: www.bioprospector.org/bioprospector/antarctica/entry.action $? \mathrm{id}=81$ such, bioprospecting has considerable scientific and economic importance. It incorporates research, discovery and extraction of genes ${ }^{\mathbf{1 3}}$ which may be of great value for public health and is currently organized under various international law regimes: the Agreement on Trade-Related Aspects of Intellectual Property Rights (TRIPS) $\frac{14}{4}$ and the Convention on Biological Diversity (CBD).$\underline{\mathbf{1 5}}$ Several principles are established by these regimes: restriction of access, intellectual property derived from patents, and possible benefit sharing.

The situation is different in Antarctica. In fact, the Antarctic Treaty System (ATS) has built over the past 50 yr a global set of ethical principles of paramount value for all activities in this region. First of all, Antarctica represents a 'natural reserve devoted to peace and science. $\frac{\mathbf{1 6}}{}$ The obligation of peaceful use is at the core of the system. The Antarctic Treaty ${ }^{\underline{17}}$ states:

It is in the interest of all mankind that Antarctica shall continue forever to be used exclusively for peaceful purposes and shall not become the scene or object of international discord [...]. Antarctica shall be used for peaceful purposes only. $\underline{18}$

As a complement to this first principle, Article IV of the Antarctic Treaty freezes all territorial claims up to the 60 degrees South. $\underline{\mathbf{1 9}}$ This fundamental obligation has numerous consequences in all questions related to the appropriation of land or resources on the continent and in the Southern Ocean. $\underline{\mathbf{2 0}}$ As part of its ethical principles, the ATS incorporates freedom for scientific research and the importance of international cooperation in accordance with 'the progress of all mankind. ${ }^{21}$ As such:

Freedom of scientific investigation in Antarctica and cooperation toward that end, as applied during the International Geophysical Year, shall continue, subject to the provisions of the present Treaty. $\underline{\underline{22}}$

${ }^{\mathbf{1 3}} \mathrm{On}$ the different phases of the bioprospecting process, see Jabour-Green \& Nicol (2003)

${ }^{14}$ Agreement on Trade-Related Aspects of Intellectual Property Rights (TRIPS), 1994: 1869 UNTS 299, 33 ILM 1197 (1994). Agreement available online: www.wto.org/english/docs_e/legal_e/27-trips.pdf

${ }^{15}$ Convention on Biological Diversity (CBD), Rio de Janeiro, 1992, EMuT, 992:42. Convention available online: www. cbd.int/doc/legal/cbd-un-en.pdf

16 Protocol on Environmental Protection to the Antarctic Treaty (PEPAT), 1991, EMuT, 991:74. Art. 2. Protocol available online: www.ats.aq/documents/recatt/Att006_e.pdf

${ }^{17}$ Antarctic Treaty, Washington, 1959, EMuT, 959:91. Treaty available online: www.ats.aq/documents/ats/treaty_original. pdf

18'There shall be prohibited, inter alia, any measures of a military nature, such as the establishment of military bases and fortifications, the carrying out of military maneuvers, as well as the testing of any types of weapons. The present Treaty shall not prevent the use of military personnel or equipment for scientific research or for any other peaceful purpose.' Antarctic Treaty, Preamble and Art. I. 
Hence, above all commercial interests, science remains the fundamental priority activity in Antarctica. $\underline{23}$ As for international cooperation in Antarctica, Article III of the Antarctic Treaty states:

In order to promote international cooperation in scientific investigation in Antarctica, [...] the Contracting Parties agree that, to the greatest extent feasible and practicable: information regarding plans for scientific programs in Antarctica shall be exchanged to permit maximum economy and efficiency of operations ${ }^{\underline{24}}$ and scientific observations and results from Antarctica shall be exchanged and made freely available. $\underline{25}$

Thus, Antarctica is a 'natural reserve' whose environmental principles must guide all activities South of 60 degrees:

The protection of the Antarctic environment and dependent and associated ecosystems and the intrinsic value of Antarctica, including its wilderness and aesthetic values and its value as an area for the conduct of scientific research, in particular research essential to understanding the global environment, shall be fundamental considerations in the planning and conduct of all activities in the Antarctic Treaty area.

To this end, activities in the Antarctic Treaty area shall be planned and conducted so as to limit adverse impacts on the Antarctic environment and dependent and associated ecosystems. $\underline{\underline{26}}$

19'1. Nothing contained in the present Treaty shall be interpreted as: a) a renunciation by any Contracting Party of previously asserted rights of or claims to territorial sovereignty in Antarctica; b) a renunciation or diminution by any Contracting Party of any basis of claim to territorial sovereignty in Antarctica which it may have whether as a result of its activities or those of its nationals in Antarctica, or otherwise; c) prejudicing the position of any Contracting Party as regards its recognition or non-recognition of any other State's right of or claim or basis of claim to territorial sovereignty in Antarctica. 2. No acts or activities taking place while the present Treaty is in force shall constitute a basis for asserting, supporting or denying a claim to territorial sovereignty in Antarctica or create any rights of sovereignty in Antarctica. No new claim, or enlargement of an existing claim, to territorial sovereignty in Antarctica shall be asserted while the present Treaty is in force.' Antarctic Treaty, Art. IV. $\stackrel{20}{\text { See infra }}$

$\underline{21}$ 'The establishment of a firm foundation for the continuation and development of such co-operation on the basis of freedom of scientific investigation [...] accords with the interests of science and the progress of all mankind.' The Treaty also states: 'It is in the interest of all mankind that Antarctica shall continue forever to be used exclusively for peaceful purposes and shall not become the scene or object of international discord [...].' Antarctic Treaty, Preamble

$\underline{22}$ Antarctic Treaty, Preamble

$\underline{23}$ Activities shall be planned and conducted in the Antarctic Treaty area so as to accord priority to scientific research and to preserve the value of Antarctica as an area for the conduct of such research, including research essential to understanding the global environment.' PEPAT, Art. 3-3

${ }^{24}$ Antarctic Treaty, Art. III-1-a)

$\underline{25}$ Antarctic Treaty, Art. III-1-c)
Together, these ethical principles represent the basis of the ATS.

How then can bioprospecting activities be organized in Antarctica to meet these fundamental ethical concerns? How can the competing requirements between freedom of scientific research, exploitation of a resource, and the differing attitudes between claimant and nonclaimant states be integrated?른 The solutions to these intractable problems are, like those of the previous Convention for the Conservation of Antarctic Seals (CCAS) $\underline{\underline{28}}$ the Convention on the Conservation of Antarctic Marine Living Resources (CCAMLR), $\underline{29}$ and the Convention on the Regulation of Antarctic Mineral Resource Activities (CRAMRA), $\underline{30}$ again in the hands of the Antarctic Treaty Parties. $\underline{31}$ Two levels of solution can be considered for bioprospecting in Antarctica, at the international and at the regional levels. But whereas the direct application of the appropriate international law regimes seems impossible within the ATS, the current Antarctic legal instruments still ignore the specific problems of bioprospecting with respect to the development of this activity in line with the Antarctic ethical principles outlined above. As a consequence, the solution for bioprospecting in Antarctica with respect to the ATS's ethical principles must rely on the creation of an ad hoc Antarctic legal instrument.

\section{INADEQUACY OF INTERNATIONAL LAW REGIMES FOR BIOPROSPECTING IN ANTARCTICA}

Bioprospecting activities occur in all parts of the world and are controlled by agreed instruments of international law manifested in national legislations. They are considered in several forums such as the United Nations (UN), the Food and Agriculture Organization (FAO), $\frac{32}{1}$ and the World Intellectual Property Organization (WIPO). It would seem obvious that the

26 PEPAT, Art. 3-1 and 2-a). See Vigni (2006)

${ }^{27}$ See Hemmings (2009), UNU-IAS (2009)

${ }^{28}$ Convention for the Conservation of Antarctic Seals (CCAS), London, 1972, EMuT, 972:41. Convention available online: www.ats.aq/documents/recatt/Att076_e.pdf

${ }^{29}$ Convention on the Conservation of Antarctic Marine Living Resources (CCAMLR), Canberra, 1980, EMuT, 980:39. Convention available online: www.ccamlr.org/pu/e/e_pubs/bd/ pt1.pdf

${ }^{30}$ Convention on the Regulation of Antarctic Mineral Resource Activities (CRAMRA), never entered into force. Convention available online: www.ats.aq/documents/recatt/ Att311_e.pdf

${ }^{31}$ For a chronology of the bioprospecting background within the ATS, see ATCM XXXII/WP026 and ATCM XXXII/IP091 in Appendix 1

32See ATCM XXXII/IP091, op. cit. 
Antarctic region could benefit from these existing legal regimes. The Convention on Biological Diversity (CBD) and the Agreement on Trade-Related Aspects of Intellectual Property Rights (TRIPS) could serve as guidelines for bioprospecting activities in Antarctica. Specific to the Southern Ocean, the United Nations Convention on the Law of the Sea (UNCLOS $)^{33}$ could also be relevant as a useful tool to organize this activity.

\section{Consideration of bioprospecting under the CBD}

The CBD is the main international instrument dealing with the protection of biodiversity. This convention recognizes the 'intrinsic value' of biological diversity, its importance 'for evolution and for maintaining lifesustaining systems of the biosphere, $\underline{\underline{34}}$ and considers its conservation as a 'common concern of humankind. $\underline{35}$ As such:

The conservation of biological diversity, the sustainable use of its components, and the fair and equitable sharing of the benefits arising out of the utilization of genetic resources, including appropriate access to genetic resources and appropriate transfer of relevant technologies, taking into account all rights over those resources and to technologies, and by appropriate funding. (Art. 1)

Similar to other international law, the CBD is firmly based on the principle of national territoriality:

States have, in accordance with the Charter of the United Nations and the principles of international law, the sovereign right to exploit their own resources pursuant to their own environmental policies, and the responsibility to ensure that activities within their jurisdiction or control do not cause damage to the environment of other states or of areas beyond the limits of national jurisdiction. (Art. 3) $)^{\underline{36}}$

${ }^{33}$ Convention on the Law of the Sea (UNCLOS), Montego Bay, 1982, EMuT, 982:92. Convention available online: www. un.org/Depts/los/convention_agreements/texts/unclos/ unclos_e.pdf

${ }^{34} \mathrm{CBD}$, Preamble

$\underline{35} \mathrm{CBD}$, Preamble

${ }^{36}$ Art. 15 further states: 'Recognizing the sovereign rights of States over their natural resources, the authority to determine access to genetic resources rests with the national governments and is subject to national legislation. Each Contracting Party shall endeavour to create conditions to facilitate access to genetic resources for environmentally sound uses by other Contracting Parties and not to impose restrictions that run counter to the objectives of this Convention [...]. Access, where granted, shall be on mutually agreed terms and subject to the provisions of this Article. Access to genetic resources shall be subject to prior informed consent of the Contracting Party providing such resources, unless otherwise determined by that Party.' CBD, Art. 15 1), 2), 4) and 5)
Indeed, the CBD is open to signature by any sovereign state party but only by state parties, making its application difficult in areas of contested sovereignty. This convention promotes the exchange of information (Art. 17). It integrates 'as far as possible and as appropriate, the conservation and sustainable use of biological diversity' (Art. 6-b) ) $^{\frac{37}{7}}$ as well as the principle of in situ conservation of biological resources (Art. 8). $\frac{\mathbf{3 8}}{}$ The distribution of benefits is generally organized pursuant to appropriate national procedures (Art. 19) meant to 'promote and advance priority access on a fair and equitable basis by Contracting Parties.' (Art. 19)

Prima facie, it appears possible to apply the CBD in Antarctica in accordance with the ethical principles of the ATS. $\stackrel{39}{ }$ However, the core question of access to the resource and its control remains unresolved. Indeed, the CBD is based on the concept of territoriality and national appropriation: 2 elements that fall foul of the requirements of Article IV of the Antarctic Treaty. $\underline{40}$ This sensitive question also raises a more general concern about peace in the sense that bioprospecting activities, if uncontrolled, could be seen as a threat to peace in Antarctica. Thus, bioprospecting seems

${ }^{37}$ Art. 10 further states: 'Each Contracting Party shall, as far as possible and as appropriate: (a) Integrate consideration of the conservation and sustainable use of biological resources into national decision-making; (b) Adopt measures relating to the use of biological resources to avoid or minimize adverse impacts on biological diversity; (c) Protect and encourage customary use of biological resources in accordance with traditional cultural practices that are compatible with conservation or sustainable use requirements [...].' CBD, Art. 10-a) to c)

${ }^{38}$ Concerning the ex-situ conservation, the CBD states: 'Each Contracting Party shall, as far as possible and as appropriate, and predominantly for the purpose of complementing in-situ measures: (a) Adopt measures for the ex-situ conservation of components of biological diversity, preferably in the country of origin of such components; (b) Establish and maintain facilities for ex-situ conservation of and research on plants, animals and micro-organisms, preferably in the country of origin of genetic resources; (c) Adopt measures for the recovery and rehabilitation of threatened species and for their reintroduction into their natural habitats under appropriate conditions; (d) Regulate and manage collection of biological resources from natural habitats for ex-situ conservation purposes so as not to threaten ecosystems and insitu populations of species, except where special temporary ex-situ measures are required under subparagraph (c) above [...].' CBD, Art. 9-a) to d)e.

${ }^{39}$ The ninth meeting of the CBD Conference of the Parties (Bonn, Germany, 19-30 May 2008) adopted decision IX/12 on access and benefit-sharing [...]. Annex I contains the draft text of the international regime, with provisions on the objective, scope, main components and nature of the international regime. Regarding the potential the scope of the International Regime on ABS currently contained in Annex 1 of decision IX/12, there arethree references to the Antarctic Treaty Area. See ATCM XXXII/IP091, op. cit. 
acceptable, desirable, and legitimate only if it matches the fundamental ethical concerns that have kept the ATS working as a model in international law over the past $50 \mathrm{yr}$. As a consequence, the CBD cannot be directly applied in the Antarctic Treaty area. However, the principles and values set out in this convention concerning the in situ conservation of the resource, the sustainable use of its components and the fair and equitable distribution of benefits could serve as general guidelines in the process of creating an ad hoc Antarctic regime for bioprospecting activities. As a complement to this, TRIPS can also be of great value.

\section{Consideration of bioprospecting under TRIPS}

Bioprospecting as organized by TRIPS incorporates the patenting of processes or products resulting from research on genetic resources. $\frac{41}{}$ As such:

The protection and enforcement of intellectual property rights should contribute to the promotion of technological innovation and to the transfer and dissemination of technology, to the mutual advantage of producers and users of technological knowledge and in a manner conducive to social and economic welfare, and to a balance of rights and obligations. (Art. 7)

A patent can be proposed for 'any inventions, whether products or processes, in all fields of technology, provided that they are new, involve an inventive step, and are capable of industrial application.' $\underline{42}$ The owner gets an exclusive right which excludes third parties from 'making, using, offering for sale, selling, or importing' $\underline{\underline{43}}$ that product. He also benefits from a protection during 'a period of twenty years counted from the filing date. $\underline{4}$ Concerning the patentable subject matter, TRIPS underlines that members 'may [...] exclude from patentability: (a) diagnostic, thera-

$\underline{40}$ Opposite positions exist in Antarctica following the interests of claimant or nonclaimant states. For instance, as mentioned during ATCM XXXII (2009): The question raised 'whether filing a patent application is considered as a claim to part of the marine environment or its resources; whether the rights conferred by a patent are likely to interfere with the right to carry out marine scientific research; and whether the degree of confidentiality required prior to the filing for patents in order to safeguard the novel character of an invention is compatible with the requirement for dissemination and publication of data and research results.' ATCM XXXII/WP026, op. cit., §4.6

$\underline{41}$ See Kevles \& Berkowitz (2001)

${ }^{42}$ For the purposes of this Article, the terms 'inventive step' and 'capable of industrial application' may be deemed by a Member to be synonymous with the terms 'non-obvious' and 'useful' respectively. TRIPS, Art. 27-1. See also Art. 29 Conditions on Patent Applicants

$\underline{43}$ TRIPS, Art. 28-1-a)

44 TRIPS, Art. 33 Term of Protection peutic and surgical methods for the treatment of humans or animals; (b) plants and animals other than microorganisms, and essentially biological processes for the production of plants or animals other than nonbiological and microbiological processes' (Art. 27$3)$. However, no strict obligation is linked to this article. Pursuant to Article 13, $\underline{\mathbf{4 5}}$ some exceptions to the exclusive right of use can be applied according to national laws. For instance, Article L.613-5 of the French Code on Intellectual Property provides for the use of the invention for fundamental research purposes, ${ }^{\mathbf{4 6}}$ but it is far from being the case for all of the TRIPS Parties. Consequently, if bioprospecting activities in Antarctica are determined as 'scientific activities,' they will have to match Article III of the Antarctic Treaty which proscribes the principle of scientific information sharing, a core element of the ATS. $\stackrel{47}{ }$ As such, even if national exceptions to the general principle of exclusive right set by TRIPS can provide a right of access to the resource, $\underline{48}$ they have no common standing with the Antarctic ethical concerns based on freedom of scientific research and scientific information exchange. This issue has been summarized during ATCM XXXII (2009) (See Appendix 1. ATCM reports and other documents):

A patent is aimed at providing for the exclusive use and exploitation of the patented invention. Since the mere isolation and characterization of a gene may often be considered an invention if sufficient inventive ingenuity has been required to isolate and characterize them, a

${ }^{45}$ Members shall confine limitations or exceptions to exclusive rights to certain special cases which do not conflict with a normal exploitation of the work and do not unreasonably prejudice the legitimate interests of the right holder. ${ }^{46}$ Greenland adopted a law to regulate bioprospecting activities (November 20, 2006). See Leary (2008)

${ }^{47}$ See supra. Article VII-5 of the Antarctic Treaty states: 'Each Contracting Party shall, at the time when the present Treaty enters into force for it, inform the other Contracting Parties, and thereafter shall give them notice in advance, of: a) all expeditions to and within Antarctica, on the part of its ships or nationals, and all expeditions to Antarctica organized in or proceeding from its territory; b) all stations in Antarctica occupied by its nationals; and c) any military personnel or equipment intended to be introduced by it into Antarctica subject to the conditions prescribed in paragraph 2 of Article I of the present Treaty.' Article VII-5 of the Treaty establishes the obligation of advance notice between the ATS Parties. Besides, Article 17 of PEPAT provides: 'Each Party shall report annually on the steps taken to implement this Protocol. Such reports shall include notifications made in accordance with Article 13 (3), contingency plans established in accordance with Article 15 and any other notifications and information called for pursuant to this Protocol for which there is no other provision concerning the circulation and exchange of information.' An Electronic Information Exchange System (EIES) has been established

${ }^{48}$ TRIPS, Art. 31 Other Use Without Authorization of the Right Holder 
patent can be granted over the exclusive use and exploitation of the genetic resource. The patent may result in excluding others from freely using that organism for further investigation and from exploiting it without a licence from the patent holder. Such an exclusion would seem to be contrary to the freedom of science. [Besides], there are 2 concerns. The first is that scientists working with private partners will often be required to seek the approval of the private partner before releasing results, and in some cases they may even be prohibited from publishing. Experience has shown that scientists that have formal partnerships with industry tend to have higher publication rates than those from non industryaligned institutes. The second is that the patenting process delays publication, as scientific data for a patent must be kept secret until the patent is filed in order to preserve the novel character of the invention. This delay may be contrary to the obligation of Article III.1(c) that results need to be made freely available. $\underline{49}$

This debate raises the question of the meaning of 'bioprospecting' as either a scientific or a commercial activity. If one decides that bioprospecting is a scientific activity, its organization in Antarctica definitely has to match the requirements set by the Treaty and the Protocol on Environmental Protection to the Antarctic treaty (PEPAT). On the other hand, if bioprospecting is treated entirely as a commercial activity, the previous obligations do not apply, and the activities proposed must (only) be submitted to environmental impact assessment (EIA) as set by Article 8 and Annex I of PEPAT. $\underline{\mathbf{5 0}}$ However, it is still very difficult to decide whether bioprospecting is a scientific or a commercial activity $\underline{\underline{51}}$ for several reasons.

Firstly, bioprospectors are often consortiums of public and private interests. For instance, the research on the Antarctic marine sponge Kirkpatrickia varialosa ${ }^{52}$ has been conducted by the private company 'PharmaMar' in partnership with the University of Barcelona.

Secondly, it is still going to be very difficult to draw a clear line between fundamental scientific research and applied research for commercial interests: $\frac{\mathbf{5 3}}{\mathbf{m}}$ the intention of the bioprospector and the final goal of the research can evolve from one state to another, $\underline{\underline{54}}$ not only within the intentions of the bioprospector, but also within the legal space distinguishing between funda-

\footnotetext{
${ }^{49} \mathrm{ATCM}$ XXXII/WP026, op. cit., §4.6

${ }^{50}$ Article 8 of PEPAT states: Proposed activities referred to in paragraph 2 below shall be subject to the procedures set out in Annex I for prior assessment of the impacts of those activities on the Antarctic environment or on dependent or associated ecosystems according to whether those activities are identified as having: (a) less than a minor or transitory impact; (b) a minor or transitory impact; or (c) more than a minor or transitory impact. See infra

$\underline{51}$ See Connolly-Stone (2005)

$\underline{52}$ Variolin B is derived from this Antarctic marine sponge and commercialized as an antitumor agent (see the United Nations University database: www.bioprospector.org/bioprospector/antarctica/entry.action?id=233)
}

mental and applied research $\underline{55}$ in different systems of national law.

Thirdly, the final application of the genetic product may be useful for both science and commerce.

This lack of precision concerning the definition of bioprospecting as a scientific or a commercial activity adds a new difficulty in its consideration by the ATS. As mentioned above with the CBD regime based on the idea of territorialism, which is definitely contrary to Article IV of the Antarctic Treaty, a consensus on applying such a governance instrument seems unlikely. The appropriation of a living resource could nonetheless be organized under the United Nations Convention on the Law of the Sea (UNCLOS). De facto, bioprospecting in Antarctica mostly concerns the marine resources of the Southern Ocean. $\frac{\mathbf{5 6}}{\text { This con- }}$ vention could be of particular relevance for bioprospecting activities in Antarctica.

\section{Consideration of bioprospecting under UNCLOS}

If bioprospecting is considered as a scientific activity, Part XIII of UNCLOS could serve as a useful tool to organize this type of marine scientific research in the Southern Ocean. It incorporates the principle of freedom of scientific research, promotes 'the peaceful uses of the seas and oceans, the equitable and efficient utilization of their resources, the conservation of their liv-

53 In 2004, it was reiterated that the distinction between fundamental and applied MSR [Marine Scientific Research] had never been accepted universally, since there was no perceivable difference in activities or methods. In that context it was generally recognized that the main distinction lies in the intent and purpose of the research, as well as the use of the knowledge and results of the research. ATCM XXXII/IP070 in Appendix 1

${ }^{54} \mathrm{As}$ mentioned by the 2008 Intersessional Contact Group (ICG): 'It was also suggested that it is relevant to consider whether different standards should apply to fundamental scientific research, applied scientific research and commercial use, and whether, in some cases, these distinctions can be made. It was noted by some participants that there are already several definitions in international instruments and national legislation that may provide some assistance in developing some guidance to distinguish between the various activities. It was noted by other participants that it will be very difficult to distinguish between such activities in practice and, therefore, that all biological prospecting activities should be subject to approval under Article 3 of Annex II of the Protocol on Environmental Protection to the Antarctic Treaty.' ATCM XXXI/WP004 in Appendix 1

${ }_{55}^{5}$ The scholars are not unanimous on the question of assimilation between bioprospecting and different types of research; this distinction remains a cause of concern. See supra

${ }^{56}$ As mentioned above by the University of the United Nations database, bioprospecting in Antarctica concerns marine (56 percent) and terrestrial organisms. Op. cit. 
ing resources, and the study, protection and preservation of the marine environment' (Preamble) and further incorporates the general, customary obligation of conservation of the marine living resources of the high

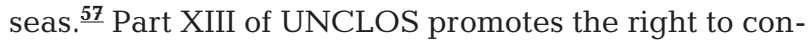
duct marine scientific research 'exclusively for peaceful purposes, ${ }^{\prime} \mathbf{5 8}$ international cooperation, (Art. 242) and the publication and dissemination of information and knowledge (Art. 244). However, UNCLOS gives no definition of 'marine scientific research,' which remains under national interpretations. Part XI of UNC$\operatorname{LOS}^{59}$ and its related Agreement ${ }^{60}$ organize prospecting activities as well as exploration and exploitation exclusively for the mineral resources of the Area ${ }^{\mathbf{6 1}}$ i.e. the polymetallic nodules located in the deep seabed. ${ }^{\mathbf{6 2}}$ These resources are considered as Common Heritage of Mankind (CHM) (UNCLOS, Art. 136) and must meet the relevant ethical requirements linked to the concept of CHM such as peace, no territorialism, free access to the resource, sustainable use, fair and equitable benefit-sharing. ${ }^{63}$ Marine scientific research in the area 'shall be carried out exclusively for peaceful purposes and for the benefit of mankind as a whole, in accordance with Part XIII' (Art. 143). A supranational body,

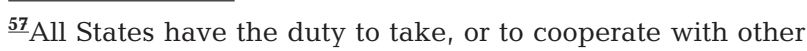
States in taking, such measures for their respective nationals as may be necessary for the conservation of the living resources of the high seas. (Art. 117)

${ }^{58}$ UNCLOS, Art. 240-a). 'All States, irrespective of their geographical location, and competent international organizations have the right to conduct marine scientific research subject to the rights and duties of other States as provided for in this Convention.' (Art. 238) Article 239 further states: 'States and competent international organizations shall promote and facilitate the development and conduct of marine scientific research in accordance with this Convention.'

${ }^{59}$ Part XI The Area

${ }^{60}$ Agreement relating to the Implementation of Part XI of the United Nations Convention on the Law of the Sea of 10 December 1982 (www.un.org/Depts/los/convention agreements/texts/unclos/closindxAgree.htm). See Scovazzi (2004)

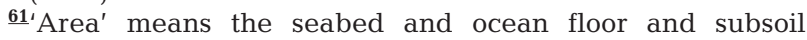
thereof, beyond the limits of national jurisdiction. UNCLOS, Art. 1-1-1)

$\underline{62}$. No State shall claim or exercise sovereignty or sovereign rights over any part of the Area or its resources, nor shall any State or natural or juridical person appropriate any part thereof. No such claim or exercise of sovereignty or sovereign rights nor such appropriation shall be recognized. 2. All rights in the resources of the Area are vested in mankind as a whole, on whose behalf the Authority shall act. These resources are not subject to alienation. The minerals recovered from the Area, however, may only be alienated in accordance with this Part and the rules, regulations and procedures of the Authority. 3. No State or natural or juridical person shall claim, acquire or exercise rights with respect to the minerals recovered from the Area except in accordance with this Part. Otherwise, no such claim, acquisition or exercise of such rights shall be recognized. UNCLOS, Art. 137 the International Seabed Authority (ISBA) shall 'carry out marine scientific research concerning the area and its resources' (UNCLOS, Art. 143) and 'organize and control activities in the area, particularly with a view to administering the resources of the area' (Agreement, Annex, Section 1-1). The decision-making relies on consensus (Section 3-2). Prospection, exploration, and exploitation are organized under the Enterprise (Section 2) which shall make:

Assessment of the results of the conduct of marine scientific research with respect to activities in the Area, with particular emphasis on research related to the environmental impact of activities in the Area (Agreement, Annex, Section 2, Art. 1-b); Assessment of available data relating to prospecting and exploration, including the criteria for such activities; (idem, c); Assessment of technological developments relevant to activities in the Area, in particular technology relating to the protection and preservation of the marine environment (...) (ibidem, d) $\underline{64}$

The Agreement also provides for the transfer of technology (Section 5) and economic assistance for developing countries (Section 7) $\underline{65}$

However, this very specific regime can only be applied to the exploitation of mineral resources of the Area, whereas biological ones still remain under the general principle of the freedom of the high seas: $\underline{\mathbf{6}}$ 'first come, first served. ${ }^{\prime 67}$ The situation could be different if one considers the possible extension of the UNCLOS regime for prospecting activities on mineral resources to living organisms of the Area. $\stackrel{68}{6}$ The CHM principles and the obligation of preservation of the resource could thus apply to living resources targeted by bioprospecting activities.

${ }^{63}$ See Mahmoudi (2000)

${ }^{64}$ Article 145 of UNCLOS further states: 'Necessary measures shall be taken in accordance with this Convention with respect to activities in the Area to ensure effective protection for the marine environment from harmful effects which may arise from such activities. To this end the Authority shall adopt appropriate rules, regulations and procedures for, inter alia: (a) the prevention, reduction and control of pollution and other hazards to the marine environment, including the coastline, and of interference with the ecological balance of the marine environment, particular attention being paid to the need for protection from harmful effects of such activities as drilling, dredging, excavation, disposal of waste, construction and operation or maintenance of installations, pipelines and other devices related to such activities; (b) the protection and conservation of the natural resources of the Area and the prevention of damage to the flora and fauna of the marine environment.'

${ }^{65}$ Article 140 of UNCLOS states: 'The Authority shall provide for the equitable sharing of financial and other economic benefits derived from activities in the Area through any appropriate mechanism, on a non-discriminatory basis $[. . .]^{\prime}$

${ }^{66}$ See Nandan et al. (2002)

${ }^{67}$ See Scovazzi $(1998,2000)$

${ }_{68}^{6}$ See Glowka (2000) 
Numerous scholars have already studied the longlasting issue of applicability, desirability, necessity and legitimacy of UNCLOS south of the 60 degrees South. ${ }^{69}$ The specific application of Part XI and the related Agreement to the protection of the living organisms of the deep seabed of the Southern Ocean needs then to incorporate 2 main considerations: (1) the extension of the UNCLOS regime for prospecting activities on mineral resources to living organisms of the Area; and (2) the delimitation of an area in the Southern Ocean with due consideration to Article IV of the Antarctic Treaty freezing all territorial claims.

Although still hypothetical and largely theoretical, this legal construct could nonetheless serve to protect the living resources of the Southern Ocean located in its deep seabed instead of leaving the actual exploitation uncontrolled with very little concern for the impacts of such activities on the Antarctic marine environment. $\underline{70}$

In conclusion, the following elements need special consideration. First of all, the universal law systems of the CBD, TRIPS and UNCLOS are a valuable background in the sense that they provide rules organizing the access, the intellectual property rights, the conditions of benefit-sharing, and the preservation of resources.

However, several core problems remain:

(1) The worldwide concept of territoriality and Article IV of the Antarctic Treaty.

(2) The balance between patent, intellectual property, and appropriation of a genetic resource on the one hand, and the Antarctic principles of freedom of scientific research and scientific information exchange on the other.

(3) As a consequence of Article IV of the Antarctic Treaty, a problem remains concerning the applicability of exclusive rights on a living resource. If not properly organized, bioprospecting in Antarctica could threaten peace and the interest of mankind, contrary to the ATS ethical principles.

(4) The question of benefit sharing for such exploitation of an Antarctic resource still remains unsolved.

(5) The environmental impacts of bioprospecting are still largely unknown. As such, this activity should match the environmental principles set by Article 3 of PEPAT and be undertaken pursuant to the precautionary approach.

The CBD, TRIPS and UNCLOS are certainly valuable sources of inspiration in the process of creation of a new ad hoc legal regime for bioprospecting in Antarctica. However, their inadequacy with respect to the ethical

${ }^{69}$ See Brennan (1983), Barnes \& Lipperman (1987), JabourGreen \& Nicol (2003), Hemmings (2005), Del Castillo Laborde (2006)

${ }^{70}$ See Francioni (1987), Hussain (1992)
ATS principles does not permit any direct application of these universal instruments in Antarctica.

\section{INADEQUACY OF ANTARCTIC LEGAL INSTRUMENTS FOR BIOPROSPECTING IN ANTARCTICA}

The ATS is based on ethical concerns established in 1959 by the Antarctic Treaty and reaffirmed by successive international instruments such as CRAMRA, CCAMLR and PEPAT. All rely on peace, a freeze on territorial claims and property, freedom of scientific research, international cooperation, and environmental protection in the interest of mankind as a whole.

The Antarctic Treaty Consultative Parties (ATCPs) ${ }^{71}$ have shown a growing interest in bioprospecting issues $\underline{\underline{72}}$ which now appears to be a priority. As mentioned by Resolution 9 (2009) Collection and use of Antarctic biological material,,$\underline{73}$ the Parties:

Reaffirm that the Antarctic Treaty System is the appropriate framework for managing the collection of biological material in the Antarctic Treaty area and for considering its use;

and

Emphasize that existing Antarctic Treaty system arrangements under the Protocol on Environmental Protection and the Convention on the Conservation of Antarctic Marine Living Resources address the environmental aspects of scientific research and the collection of biological material in the Antarctic region. ${ }^{\mathbf{7 4}}$

The Antarctic Treaty Consultative Meeting (ATCM) approach has often proven to be proactive in the solu-

${ }^{71}$ There are currently 28 ATCPs (2009). List of the ATCPs available at www.ats.aq/devAS/ats_parties.aspx?lang=e ${ }^{72}$ The bioprospecting issue has been firstly raised in Antarctica in 1999 by the SCAR while the debates started in 2001 following a United Kingdom proposal. Subsequently, this item has been included in 2001 to the CEP Agenda and in 2004 to the ATCM's. The ATCM adopted Resolution 7(2005) Biological Prospecting to recall the importance of the principles of freedom of scientific research and information sharing (www.ats.aq/devAS/info_measures_listitem.aspx?lang= e\&id=352). An ICG was organized in 2007 as well as workshops (2003 and 2009). See also the documents: ATCM XXV/WP043, ATCM XXVI/IP047, ATCM XXVI/IP075, ATCM XXVII/IP106, ATCM XXVIII/WP013, ATCM XXVIII/IP008, ATCM XXVIII/IP093，ATCMXXIX/IP013, ATCM XXIX/IP112, ATCM XXIX/IP116, ATCM XXX/WP036, ATCM XXX/IP067, ATCM XXXI/WP004, ATCM XXXI/WP011, ATCM XXXII/WP001, ATCM XXXII/WP018, ATCM XXXII/WP026, ATCM XXXII/WP049, ATCM XXXII/IP065, ATCM XXXII/IP070, ATCM XXXII/IP084, ATCM XXXII/IP091, ATCM XXXII/IP115. For a genesis of the bioprospecting background within the ATS, see supra

${ }^{73}$ www.ats.aq/devAS/info_measures_listitem.aspx?lang=e\& id $=450$ 
tion of problems, and the first stages of important discussions are currently in progress in order to organize this new activity with respect to the ATS ethical principles. The main question remains the balance between bioprospecting, patent and exclusive rights on the one hand, and freedom of scientific research and international cooperation through scientific information exchange on the other: the control over access to the targeted resource is the source of concern.

No clear solution has been reached so far concerning the balance between the exclusive owner's rights and the specific question of property linked to the original territorial claims in Antarctica (Antarctic Treaty, Article IV). Article IV of the Treaty remains the core answer to property questions, and the only commercial exploitation of Antarctic resources relies on the CAMLR convention..$\underline{75}$

Concerning information sharing, a solution could be reached if one makes a distinction between 'scientific observations and results from Antarctica' and 'invention.' As such, it has been suggested in 2009 by some Parties that:

It is difficult to see any inconsistency with the requirements of Article III.1.c of the Treaty from the creation of intellectual property related to Antarctic biological material in this way. The objects of patents are not 'scientific observations and results from Antarctica' but rather inventions associated with biological material that has been collected there. Furthermore, the patent owner is obliged to publish the full details of the invention, making this information freely available. An additional consideration is that as the discovery, product development, manufacturing, and marketing stages of the bioprospecting chain occur outside Antarctica, domestic law would seem to be the most appropriate way to regulate them, as is the case at present. $\underline{76}$

Subsequent to this distinction, the problem of access to the targeted resource could find a solution and as such, 'the patenting of substances and/or technology derived from genetic resources, resulting from biological prospecting in the Antarctic Treaty Area, would not seem to be inconsistent with Art. III. 1 [of the Antarctic Treaty]. ${ }^{\underline{77}}$ However, despite the efforts of the Parties, a

\footnotetext{
${ }^{74}$ Decision available online: www.ats.aq/devAS/info_measures_listitem.aspx?lang=e\&id $=450$ As such, The Netherlands, Belgium and France supported the position under which 'the ATCM should not wait for the results of the work in these international forums, but should take the lead on the question of biological prospecting in Antarctica.' ATCM XXX/WP036 in Appendix 1. See also ATCM XXXII/IP070, Point 4, which states: 'In the Antarctic Treaty Area, there is a specific legal framework that implies that specific definitions have to be found for its context in order to arrive at an agreed regulatory regime for biological prospecting south of 60 degrees South.'

${ }^{75}$ See infra

${ }^{76}$ ATCM XXXII/WP018 in Appendix 1
}

core question remains concerning the applicability of the current ATS instrument to the bioprospecting issue: both CCAMLR and PEPAT seem insufficient to meet the ATS ethical concerns in organizing bioprospecting.

\section{Consideration of bioprospecting under CCAMLR}

As mentioned by the International Union for Conservation of Nature (IUCN):

56 percent of the records in the current IUCN Antarctic Bioprospecting Database are from the marine environment and include marine species, such as krill, in which CCAMLR has an interest. .78 $^{-1}$

The CCAMLR organizes the exploitation of marine living resources and scientific research in the Southern Ocean up to the Antarctic Convergence (Polar Front) limit. ${ }^{\mathbf{7 9}}$ Parties to the CCAMLR 'agree that they will not engage in any activities in the Antarctic Treaty area contrary to the principles and purposes of that Treaty [...].' (Art. III). Moreover, the convention states that 'all Contracting Parties, whether or not they are Parties to the Antarctic Treaty, are bound by Articles IV and VI of the Antarctic Treaty in their relations with each other' (Art. IV-1). $\underline{\mathbf{8 0}}$ The objective of the convention is 'the conservation of Antarctic marine living resources. $\frac{\mathbf{8 1}}{}$ Article II further states:

Any harvesting and associated activities in the area to which this Convention applies shall be conducted in accordance with the provisions of this Convention and with the following principles of conservation:

a) prevention of decrease in the size of any harvested population to levels below those which ensure its stable recruitment. For this purpose its size should not be allowed to fall below a level close to that which ensures the greatest net annual increment;

${ }^{77}$ See ATCM XXXI/WP004, op. cit., p.5.

${ }^{78} \mathrm{As}$ such, 'IUCN noted the international discussions on regulation of bioprospecting are also evolving, particularly in ATCM and the UN Ad Hoc Open-Ended Informal Working Group to Study Issues relating to the Conservation and Sustainable Use of Marine Biological Diversity Beyond Areas of National Jurisdiction, and that these discussions may have implications for CCAMLR. IUCN encouraged CCAMLR to actively engage in these discussions.' CCAMLR Report of the Twenty-Seventh Meeting of the Commission, $\$ 15.10$ (www.ccamlr.org/pu/e/e_pubs/cr/08/i15.pdf). See also the document CCAMLR-XXVII/BG/36, IUCN in Appendix 1

${ }^{79}$ CCAMLR, Art. I-1. 'The Antarctic Convergence shall be deemed to be a line joining the following points along parallels of latitude and meridians of longitude: $50^{\circ} \mathrm{S}, 0^{\circ} ; 50^{\circ} \mathrm{S}$, $30^{\circ} \mathrm{E} ; 45^{\circ} \mathrm{S}, 30^{\circ} \mathrm{E} ; 45^{\circ} \mathrm{S}, 80^{\circ} \mathrm{E} ; 55^{\circ} \mathrm{S}, 80^{\circ} \mathrm{E} ; 55^{\circ} \mathrm{S}, 150^{\circ} \mathrm{E}$; $60^{\circ} \mathrm{S}, 150^{\circ} \mathrm{E} ; 60^{\circ} \mathrm{S}, 50^{\circ} \mathrm{W} ; 50^{\circ} \mathrm{S}, 50^{\circ} \mathrm{W} ; 50^{\circ} \mathrm{S}, 0^{\circ}$.' $^{\prime}$ Art. I-4)

${ }^{80}$ Article V further states: 'The Contracting Parties which are not Parties to the Antarctic Treaty acknowledge the special obligations and responsibilities of the Antarctic Treaty Consultative Parties for the protection and preservation of the environment of the Antarctic Treaty area.'

81 CCAMLR, Art. II-1 
b) maintenance of the ecological relationships between harvested, dependent and related populations of Antarctic marine living resources and the restoration of depleted populations to the levels defined in subparagraph (a) above; and

c) prevention of changes or minimization of the risk of changes in the marine ecosystem which are not potentially reversible over two or three decades, taking into account the state of available knowledge of the direct and indirect impact of harvesting, the effect of the introduction of alien species, the effects of associated activities on the marine ecosystem, and the effects of environmental changes, with the aim of making possible the sustained conservation of Antarctic marine living resources.

But whereas scientific research is free (Preamble), the exploitation of resources is strictly constrained by the Conservation Measures adopted by the CAMLR Commission. The CCAMLR provides its own set of measures to achieve the conservation of the Antarctic environment and dependent and associated ecosystems. To do so, the Commission and the Scientific Committee organize and regulate the exploitation of marine living resources of the Southern Ocean. As such, the CCAMLR surely has a role to play regarding the bioprospecting issue.

However, the principles and criteria related to rational use of the resource following this convention appear mostly inadequate: they rely on a concept of the resource linked to the catch levels and its diverse effects on the trophic web. 'Antarctic marine living resources' means 'the populations of fin fish, molluscs, crustaceans, and all other species of living organisms, including birds, found south of the Antarctic Convergence. ${ }^{\prime 22}$ The value of the resource remains in the resource itself. The concept sustaining bioprospecting is completely different: for instance, the value of ice-fish Notothenia rossii is not based on the market price but rather on its genetic ability linked to the creation of derived products - which actually most of the time have very little to do with the fishery industry. Hence, contrary to the CCAMLR regime, the goal is not food-related, but much more linked to the creation of medical, pharmaceutical, or agriculture and aquaculture compounds. The value of the target relies on the knowledge derived from the genetic invention. Following the bioprospecting approach, the ice fish has no real commercial value per se; on the contrary, its antifreeze genes represent potential financial benefits linked to its use in agriculture for instance. $\underline{\underline{83}}$ Consequently, even if bioprospecting and fishery both deal with the exploitation of marine living resources, the con-

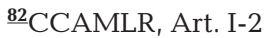

${ }^{83}$ See the uses of this gene on the website: www.biopro spector.org
}

ceptual differences between these activities seem too important to enable the proper management of bioprospecting activities by the current CCAMLR system. $\underline{\underline{84}}$

\section{Consideration of bioprospecting under PEPAT}

PEPAT was adopted in 1991 and entered into force in 1998. It applies to 'all activities' conducted in Antarctica. As such, bioprospecting activities organized in the Antarctic Treaty area must follow the prior obligation of an Environmental Impact Assessment (EIA) settled by Article 8 and Annex I of PEPAT:

Each Party shall ensure that the assessment procedures set out in Annex I are applied in the planning processes leading to decisions about any activities undertaken in the Antarctic Treaty area pursuant to scientific research programs, tourism, and all other governmental and nongovernmental activities in the Antarctic Treaty area for which advance notice is required under Article VII (5) of the Antarctic Treaty, including associated logistic support activities. $\frac{85}{}$

This global EIA procedure applies to all activities located below $60^{\circ} \mathrm{S}$. However, as mentioned above, the environmental impact of scientific collection is still largely unknown:

Insofar as is known, no impact on the Antarctic environment or its ecosystems has been caused by the collection of samples of water, soil sediments, or ice that contain these types of organisms. However, the introduction of procedures for the screening of microorganisms residing on or into other Antarctic organisms or for the collection of samples of water, soil sediment or ice in a particular environment could cause significant perturbations to the screened organisms or sampled ecosystems. The application of such procedures should therefore be carefully evaluated by individual Parties before approval. $\underline{\mathbf{8 6}}$

At the time of the adoption of PEPAT in 1991, bioprospecting was not such an important issue as it is now. There is absolutely no mention of it in this legal instrument, and a lot of uncertainties remain concerning the applicability of the current EIA process and criteria on bioprospecting activities.

${ }^{84} \mathrm{On}$ the impossible assimilation between fishery activities and bioprospecting, see Scovazzi (2004, p 400-401) 85PEPAT, Art. 8-2

${ }^{86}$ ATCM XXXI/WP004, op. cit., p.5. See also Jabour-Green \& Nicol (2003, p 85): 'In the case of micro-organism samples, only very small quantities are taken (in some cases teaspoonfuls) and the activity of collection is almost certain to cause 'less than a minor or transitory impact' on the environment. The same cannot be said for harvesting of biological resources for the purpose of extracting target compounds. This may well have a significant impact on the environment and will therefore be subject to a higher level of environmental impact assessment.' 
First, the EIA system as organized by Annex I of PEPAT shows intrinsic gaps linked to the ratione loci and ratione materiae areas. For instance, the exploitation of the genetic resources of an algae located onshore at the Antarctic Peninsula could match the ratione materiae and ratione loci framework of both of these instruments. $\stackrel{87}{ }$ Besides, the general logic of the EIA process and the level of evaluation to be done are still matters of concern. $\underline{\mathbf{8 8}}$ The environmental impacts of bioprospecting are still unknown, but some Parties rely on the presumption that this activity will have 'no more than a minor or transitory' effect on the Antarctic environment. As a consequence, bioprospecting activities may be subject to the simplest level of EIA: the preliminary stage. Annex I of PEPAT states:

1. The environmental impacts of proposed activities referred to in Article 8 of the Protocol shall, before their commencement, be considered in accordance with appropriate national procedures.

2. If an activity is determined as having less than a minor or transitory impact, the activity may proceed forthwith. (Art. 1)

During this preliminary stage, the EIA procedure remains entirely within the hands of the initiating Party which is then judge and jury to the decision. No additional comments or references are needed, as is the case for a higher EIA stage such as the Initial Environmental Evaluation (IEE) which must include:

(a) a description of the proposed activity, including its purpose, location, duration, and intensity; and

(b) consideration of alternatives to the proposed activity and any impacts that the activity may have, including consideration of cumulative impacts in the light of existing and known planned activities. (PEPAT, Annex I, Art. 2).

Following this approach, no proposed bioprospecting activity will ever be submitted to the PEPAT Envi-

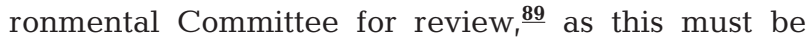
done only for activities that will have 'more than a minor or transitory impact' on the environment (Comprehensive Environmental Evaluation, CEE). $\underline{\mathbf{9 0}}$

Any kind of EIA in Antarctic must respect the environmental principles set by Article 3 of PEPAT:

Activities in the Antarctic Treaty area shall be planned and conducted so as to avoid:

(I) adverse effects on climate or weather patterns;

${ }^{87}$ Similar problematic rise concerning marine scientific research in the Southern Ocean. See Nichol (2001), Marcelli (2006), Guyomard (2010)

${ }^{88}$ See Guyomard (2010)

${ }^{89}$ The functions of the Committee shall be to provide advice and formulate recommendations to the Parties in connection with the implementation of this Protocol, including the operation of its Annexes, for consideration at Antarctic Treaty Consultative Meetings, and to perform such other functions as may be referred to it by the Antarctic Treaty Consultative Meetings [...]. PEPAT, Art.12-1
(II) significant adverse effects on air or water quality; (III) significant changes in the atmospheric, terrestrial (including aquatic), glacial, or marine environments; (IV) detrimental changes in the distribution, abundance or productivity of species or populations of species of fauna and flora;

(V) further jeopardy to endangered or threatened species or populations of such species; or

(VI) degradation of, or substantial risk to, areas of biological, scientific, historic, aesthetic or wilderness significance.

However, very little scientific research has been undertaken so far to determine if these criteria suffice for the evaluation of bioprospecting activities. $\frac{91}{}$ As such, bioprospecting activities will be authorized following the application of criteria that may be insufficient to evaluate their real impact on the Antarctic environment. Indeed, more research is needed to adapt this general EIA procedure to this specific activity, should it be organized on the Antarctic continent or in the Southern Ocean. Besides, with no supranational authority, opportunist approaches from the bioprospectors searching for the weakest national law can be expected. Even if this legal framework from the PEPAT could be used to control bioprospecting activities, its practical implementation for this specific activity is still largely unpredictable.

Hence, management of bioprospecting activities only by CCALMR and/or PEPAT appears unlikely to ensure the adequate control of this activity. Bioprospecting is a global issue that can only be organized successfully within a global framework. Thus, one of the solutions could rely on a comprehensive approach not only based on cooperation between PEPAT and CCAMLR, but on a third ad hoc instrument which could provide the basis for a terrestrial and marine legal regime applicable to all bioprospecting activities in Antarctica up to the Antarctic Convergence. In this process, CRAMRA could serve as a very useful tool.

\section{Consideration of bioprospecting under CRAMRA}

CRAMRA was adopted by the ATCPs in 1988 but never entered into force. $\frac{\mathbf{9 2}}{}$ Despite its abandonment,

\footnotetext{
${ }^{90}$ Annex I of PEPAT states: 'The draft Comprehensive Environmental Evaluation shall be forwarded to the Committee at the same time as it is circulated to the Parties [...] for consideration as appropriate. No final decision shall be taken to proceed with the proposed activity in the Antarctic Treaty area unless there has been an opportunity for consideration of the draft Comprehensive Environmental Evaluation by the Antarctic Treaty Consultative Meeting on the advice of the Committee [...].'

91 See ATCM XXXII/IP065: SCAR in Appendix 1
} 
numerous elements of its drafting can still be seen as a source of inspiration. In the 1980s, huge efforts had already been made in order to organize the exploration and exploitation of Antarctic mineral resources in a way compatible with Article IV of the Antarctic Treaty (See CRAMRA Preamble and Art. 9). This convention organized the conduct of activities 'with a view to safeguarding the protection of the Antarctic environment in the interest of all mankind' (Art. 2-3-g). A primary distinction had been made between scientific research activities and other activities $\underline{\underline{93}}$ like prospecting on mineral resources, $\underline{94}$ as well as exploration $\underline{95}$ and exploitation. Each of these stages was defined (Art. 1-8 to 1-10). CRAMRA had ducked the question of access to the resource and relied, as far as possible, on the exchange of information (Art. 16), providing that 'prospecting shall not confer upon any Operator any right to Antarctic mineral resources. $\underline{96}$ CRAMRA was meant to oversee all activities related to the exploitation of mineral resource in Antarctica. It settled an EIA system organized to limit:

Any impact on the living or nonliving components of that environment or those ecosystems, including harm to atmospheric, marine, or terrestrial life, beyond that which is negligible or which has been assessed and judged to be acceptable pursuant to this Convention. $\underline{.7}^{97}$

The concept of deep seabed based on UNCLOS was integrated into the Convention (Art. 5-3). CRAMRA was also based on the cooperation between operators

$\overline{\underline{92} \text { See Joyner (1991) }}$

93 "Antarctic mineral resource activities' means prospecting, exploration or development, but does not include scientific research activities within the meaning of Article III of the Antarctic Treaty.' CRAMRA, Art. 1-7.7

94" Prospecting' means activities, including logistic support, aimed at identifying areas of mineral resource potential for possible exploration and development, including geological, geochemical and geophysical investigations and field observations, the use of remote sensing techniques and collection of surface, sea floor and sub-ice samples. Such activities do not include dredging and excavations, except for the purpose of obtaining small-scale samples, or drilling, except shallow drilling into rock and sediment to depths not exceeding 25 metres, or such other depth as the Commission may determine for particular circumstances.' CRAMRA, Art. 1-8

95“"Exploration' means activities, including logistic support, aimed at identifying and evaluating specific mineral resource occurrences or deposits, including exploratory drilling, dredging and other surface or subsurface excavations required to determine the nature and size of mineral resource deposits and the feasibility of their development, but excluding pilot projects or commercial production.' CRAMRA, Art. 1-9

96 CRAMRA, Art. 37-1

${ }^{97}$ CRAMRA, Art. 1-15. See also CRAMRA (Art. 4-2) and PEPAT (Art. 3-2-b) which settle the basic criterion to define the ecological damage so as to ensure a fair and nondiscriminative participation among the ATCPs (Art. 6 and 14). A supranational body - the Commission - was in charge of examining the demands with the cooperation of the Scientific Committee (Art. 23) in order to authorize or not the proposed activities (Art. 21). Hence, the core of this system was based on a balance between rights of access and Art. IV of the Treaty (Art. 37-4 and 37-5). $\underline{\text { 98 }}$ Eventually, this convention provided also for an inspection system to be used for the infrastructure of exploitation $^{99}$ as well as a strict liability regime for environmental damage. $\stackrel{\mathbf{1 0 0}}{ }$

Thus, an adaptation of this convention to Antarctic living organisms could definitely serve as a useful tool in the process of creating a new ad hoc legal regime for bioprospecting in Antarctica matching the ATS ethical requirements.

\section{CONCLUSIONS}

Bioprospecting in Antarctica will only be legitimate if it matches the core ATS ethical principles: $\frac{\mathbf{1 0 1}}{}$ peace, a freeze on territorial claims and property, freedom of scientific research and exchange of information, international cooperation, and environmental protection in the interest of mankind as a whole. Considering the specificity of this system based on Article IV of the Treaty, the present international instruments seem inadequate to organize this activity in Antarctica but could definitively serve as sources of inspiration for developing new tools. On the applicability of the actual ATS instruments to bioprospecting activities, several elements can be recalled:

(1) Bioprospecting concerns both terrestrial and marine ecosystems. This scientific consideration must influence the creation of a comprehensive Antarctic legal instrument encompassing equally both ecosystems (instead of separating the bioprospecting activities pursuant to the CCAMLR or PEPAT depending on whether the target is in the marine or terrestrial ecosystem). $\underline{\mathbf{1 0 2}}$

(2) The legal regime for bioprospecting in Antarctica should be based on the actual EIA process applicable to all activities in Antarctica. However, the criterion of PEPAT Annex I should be reviewed so as to take into

\footnotetext{
98 This compromise also found an echo in the composition of the different bodies: each ATCP had a veto power in the decision process of the Commission and the Committee. Whatever the practice could have been, the CRAMRA system was firmly enabled to go beyond the intrinsic ATS obstacles ${ }^{99}$ CRAMRA, Art. 12

${ }^{100}$ CRAMRA, Art. 8-2

${ }^{101}$ See Johnston \& Lohan (2005a,b), Guyomard (2006)

${ }^{102}$ See Battaglia et al. (1997), Knox (2006)
} 
account the specific environmental risks linked to bioprospecting activities.

(3) More scientific knowledge is needed concerning the specific risks of bioprospecting on the different Antarctic species. In the meantime, the precautionary approach should be employed.

Bioprospecting is a current activity in Antarctica whose environmental impacts are still unknown. Even if the research, exploitation, and patent of Antarctic genetic resources are organized under international legal instruments, their principles and environmental standards will not match the ethical standards already established by the Antarctic Treaty and its Environmental Protocol. Considering this inadequacy and the insufficiency of CCAMLR and PEPAT to organize this new activity, an ad hoc legal regime for bioprospecting in Antarctica is needed. As such, bioprospecting will only be legitimate if it matches the ethical principles of the ATS.

Acknowledgements. I thank Professor Tullio Scovazzi for his invaluable support and cooperation, the referees for commenting on the early draft of this article, and my friends and colleagues K. Argudo and W. LaJuana for their generous help on the review of this article in English.

\section{LITERATURE CITED}

Barnes \& Lipperman (1987) UNCLOS and Antarctica. In: Francioni F, Scovazzi T (eds) International law for Antarctica. Giuffrè Publishing, Milan p 367-379

Battaglia B, Valencia J, Walton DWH (1997) Antarctic communities. species, structure and survival. Cambridge University Press, Cambridge

Brennan K (1983) Criteria for access to the resources of Antarctica: alternatives, procedure and experience applicable. In: Orrego Vicuña F (ed) Antarctic resources policy: scientific, legal and political issues. Cambridge University Press, Cambridge, p 217

Connolly-Stone K (2005) Patents, property rights and benefit sharing issues in relation to bioprospecting. In: Hemmings $\mathrm{AD}$, Rogan-Finnemore M (eds) Antarctic bioprospecting. Gateway Antarctica Special Publication Series Number 0501, Christchurch

Del Castillo Laborde L (2006) UNCLOS, Antarctica and the environment. In: Tamburelli G (ed) The Antarctic legal system and environmental issues. Istituto di Studi Giuridici Internazionali, Giuffrè Editore, Milan, p 97-120

Francioni F (1987) Antarctica and the Common Heritage of Mankind. In: Francioni F, Scovazzi T (eds) International law for Antarctica. Giuffrè Publishing, Milan, p 101-136

Glowka L (2000) Beyond the deepest of ironies: genetic resources, marine scientific research and international seabed area. In: Beurier JP, Kiss A, Mahmoudi S (eds) Nouvelles technologies et droit de l'environnement marin. Kluwer, The Hague, p 75-94

Guyomard AI (2006) Bioprospecting in Antarctica: a new challenge for the Antarctic Treaty System. In: Francioni F, Scovazzi $T$ (eds) Biotechnology and international law. Hart Publishing, Oxford, p 147-169
Guyomard AI (2010) La protection de l'environnement en Antarctique - droit international et droit comparé. PhD thesis, Publication of the Law of the Sea and Maritime Law Center - CDMO, Nantes University of Law and Political Sciences, Vol I \& II $(811 p+476 p)$

Hemmings AD (2005) A question of politics: bioprospecting and the Antarctic Treaty System. In: Hemmings $A D$, Rogan-Finnemore M (eds) Antarctic bioprospecting. Gateway Antarctica Special Publication Series Number 0501, Christchurch, p 89-129

Hemmings AD (2009) From the new geopolitics of resources to nanotechnology: emerging challenges of globalism in Antarctica. Yearbook of Polar Law 1:55-72

Hemmings AD, Rogan-Finnemore M (2005) Antarctic bioprospecting. Workshop Gateway Antarctica April 7-8, Gateway Antarctica Special Publication Series Number 0501, Christchurch

Jabour-Green J, Nicol D (2003) Bioprospecting in areas outside national jurisdiction: Antarctica and the Southern Ocean. Melbourne J Int Law 4:76-111

Johnston S, Lohan D (2005a) The international regime for bioprospecting: existing policies and emerging issues for Antarctica. In: Hemmings A, Rogan-Finnemore M (eds) Antarctic bioprospecting. Gateway Antarctica Special Publication Series Number 0501, Christchurch

Johnston S, Lohan D (2005b) Bioprospecting in Antarctica, United Nations University - Institute of Advanced Studies Report. Available at: www.ias.unu.edu/binaries2/antarctic_bioprospecting.pdf

Joyner CC (1991) CRAMRA: The ugly duckling of the Antarctic Treaty System? In: Jørgensen-Dahl A, Østreng W (eds) The Antarctic Treaty System in world politics. The Fridtjof Nansen Institute, Lysaker, p 161-185

Kevles DJ, Berkowitz A (2001) The gene patenting controversy: a convergence of law, economic interests and ethics. Brooklyn Law Rev 67:233-248

Knox G (2006) Biology of the Southern Ocean. Cambridge University Press, Cambridge

Leary D (2008) Greenland's new legislation on commercial and research-related use of biological resources: implications for the International Polar Year and later. Polar Rec 44:97-106

Levin S (2000) The encyclopedia of biodiversity, 2nd edn. Princeton University, NJ

Mahmoudi S (2000) Common Heritage of Mankind, common concern of humanity. In: Beurier JP, Kiss A, Mahmoudi S (eds) Nouvelles technologies et droit de l'environnement marin. Kluwer, The Hague, p 215-223

Marcelli F (2006) Scientific research in the Antarctic: general principles and concrete actions. In: Tamburelli G (ed) The Antarctic legal system and environmental issues. Istituto di Studi Giuridici Internazionali, Giuffrè Editore, Milano, p 57-76

Nandan S, Lodge M, Rosenne S (2002) The development of the regime for deep seabed mining. International Seabed Authority, Kingston

Nichol DS (2001) Case studies of biotechnology opportunities in Antarctica. In: Looking south - managing technology, opportunities and the global environment. Australian Academy of Technological Sciences and Engineering, Parkville

Scovazzi T (1998) La liberté de la mer: vers l'affaiblissement d'un principe vénérable? Annuaire de Droit Maritime (A.D.M.), 1998, Nantes, p 13-29

Scovazzi T (2000) The evolution of international law of the sea: new issues, new challenges. Recueil des Cours de l'Académie de Droit International de La Haye, no. 39 
Scovazzi T (2004) Mining, protection of the environment, scientific research and bioprospecting: some considerations on the role of the International Sea-Bed Authority. Int J Mar Coast Law 19:383-409

UNU-IAS (2009) Looking beyond the International Polar Year: emerging and re-emerging issues in international law and policy in the polar regions. In: Alfredsson G,
Koivurova T, Leary D (eds) The yearbook of polar law, Vol 1. Brill Martinus Nijhoff, Leiden

Vigni (2006) Antarctic bioprospecting: Is it compatible with the value of Antarctica as a natural reserve? In: Francioni F, Scovazzi T (eds) Biotechnology and international law. Hart Publishing, Portland, OR, p 111-145

Appendix 1. ATCM reports and other documents

\section{Antarctic Treaty consultative meetings documents}

ATCM XXXII/IP065 SCAR: Biological prospecting in the Antarctic: An update on the review by SCAR. (www.ats.aq/documents/ATCM32/ip/ATCM32_ip065_e. doc)

ATCM XXXII/IP070: Sweden, Belgium, Finland, France, The Netherlands, Spain: Concepts, Terms and Definitions, including a Comparative Analysis (www.ats. aq/documents/ATCM32/ip/ATCM32_ip070_e.doc)

ATCM XXXII/IP091 UNEP: Biological Prospecting: An update on recent policy developments at the international level (www.ats.aq/documents/ATCM32/ip/ATCM32_ip 091_e.doc)

ATCM XXXII/WP018: Australia, New Zealand: Regulation of biological prospecting under the Antarctic Treaty system (www.ats.aq/documents/ATCM32/wp/ATCM32 wp018_e.doc)

ATCM XXXII/WP026: The Netherlands, Belgium, Bulgaria, Finland, France, Germany, Spain, Sweden: A gap analysis of the Antarctic Treaty system regarding the management of biological prospecting (www.ats.aq/documents/ATCM32/wp/ATCM32_wp026_e.doc)

ATCM XXXI/WP004 The Netherlands: Report of the ATCM Intersessional Contact Group to examine the issue of Biological Prospecting in the Antarctic Treaty Area, p.5 (www.ats.aq/documents/ATCM31/wp/ATCM31_wp0 04_e.doc)

ATCM XXXI/WP011 Belgium: An update on biological prospecting in Antarctica, including the development of the Antarctic Biological Prospecting Database (www.ats.
aq/documents/ATCM31/wp/ATCM31_wp011_e.doc)

ATCM XXX/WP036: The Netherlands, Belgium, France: Biological Prospecting in the Antarctic Treaty Area - Scoping for a Regulatory Framework, p.3 (www.ats.aq/documents/ATCM30/wp/ATCM30_wp036_e.doc)

Resolution ATCM 7 (2005) Biological Prospecting (www. ats.aq/devAS/info_measures_listitem.aspx?lang=e\&id=352)

Resolution ATCM 9(2009) Collection and use of Antarctic biological material (www.ats.aq/devAS/info_measures_listitem.aspx?lang=e\&id=450)

\section{Additional ATCM documents}

ATCM XXXII/WP001, ATCM XXXII/WP049, ATCM XXXII/IP084, ATCM XXXII/IP115, ATCM XXX/IP067, ATCM XXIX/IP013, ATCM XXIX/IP112, ATCM XXIX/IP116, ATCM XXVIII/WP013, ATCM XXVIII/IP008,ATCM XXVIII/IP093, ATCM XXVII/IP106, ATCM XXVI/IP047, ATCM XXVI/IP075, ATCM XXV/WP043.

\section{Other relevant documents and website}

CCAMLR-XXVII/BG 36, IUCN: Biological prospecting in the Antarctica Treaty area: a role for CCAMLR. www.bioprospector.org

UNU-IAS (2005): Bioprospecting of Genetic Resources in the Deep Seabed: Scientific, Legal and Policy Aspects (www.ias.unu.edu/binaries2/DeepSeabed.pdf) 